\title{
Fiscal decentralization, revenue and expenditure assignments, and growth in China
}

\author{
Jing Jin ${ }^{\mathrm{a}, 1}$, Heng-fu Zou ${ }^{\mathrm{b}, \mathrm{c}, *}$ \\ ${ }^{a}$ Central University of Finance and Economics, 39, South College Road, \\ Haidian District, Beijing 100081, China \\ ${ }^{\mathrm{b}}$ Peking University and Wuhan University, China \\ ${ }^{\mathrm{c}}$ Research Department, The World Bank, MC3-639, 1818 H. St. NW, \\ Washington, DC 20433, USA
}

Received 1 July 2005; received in revised form 15 September 2005; accepted 12 October 2005

\begin{abstract}
Theory suggests that a close match between revenue and expenditure assignments at sub-national levels benefits allocative efficiency, and hence economic growth. That is, a convergence of revenue and expenditure assignments at sub-national levels of government should, according to the theory, be positively associated with a higher growth rate. In the case of China, this paper shows, divergence, rather than convergence, in revenue and expenditures at the sub-national level of government is associated with higher rates of growth. A panel dataset for 30 provinces in China is used to examine the relationship between fiscal decentralization and economic growth over two phases of fiscal decentralization in China: (1) 1979-1993 under the fiscal contract system, and (2) 1994-1999 under the tax assignment system. The seeming contradiction between the theory and evidence in the China case is reconciled by taking into account the institutional arrangements that prevailed during the two phases of fiscal decentralization, in particular the inconsistency between the assumptions of the theory of fiscal decentralization and the institutional reality of China.
\end{abstract}

(C) 2005 Elsevier Inc. All rights reserved.

JEL classification: $\mathrm{H} 2 ; \mathrm{H} 7 ; \mathrm{O} 1$

Keywords: Fiscal decentralization; Economic growth; Revenue; Expenditure

* Corresponding author at: Research Department, The World Bank, MC3-639, 1818 H. St. NW, Washington, DC 20433, USA. Tel.: +1 202473 7939; fax: +1 2025221154 .

E-mail addresses: jjin68@ hotmail.com (J. Jin), Hzou@worldbank.org (H.-f. Zou).

${ }^{1}$ Tel.: +86137 175 41581; fax: +861062289132. 


\section{Introduction}

Since initiating economic reforms in 1978, fiscal decentralization has been a central component of China's economic policy at a time when China has experienced unprecedented economic growth. Although China remains a unitary political system, where sub-national government elections are virtually not exist, its fiscal system is nevertheless a decentralized one featured by a fiscal contract system (1980-1993) ${ }^{1}$ and revenue assignment system (1994present). Regardless of China's non-democratic institutions, the benefits of fiscal decentralization seem still applicable, according to Oates (1972, p. xvi), because "for an economist, however, constitutional and political structures are of less importance: What is crucial for him is simply that different levels of decision-making do exist, each of which determines levels of provision of particular public services in response largely to the interests of its geographical constituency. By this definition, practically any fiscal system is federal or at least possesses federal elements".

The question of whether fiscal decentralization has contributed to China's economic success over the past 20 years is, however, open to debate. Some argue that fiscal decentralization has been fundamental to China's economic success (Oi, 1992; Qian, 1999; Qian \& Weingast, 1997). It has been asserted that the fiscal contract system (1980-1993) provided material incentives that encouraged and rewarded sub-national governments to promote local economies (Oi, 1992; Qian, 1999). Secondly, Qian (1999) assumes that sub-national governments had less control over banks and therefore could not bail out their state-owned enterprises (SOEs) by extending credit to them as the central government did. Fiscal decentralization, they argue, hardened the budget constraints of sub-national governments' SOEs, and thus made these SOEs more efficient (Qian, 1999). The fiscal contract system, it is also asserted, allowed sub-national governments to conceal information about their financial position and enabled them to avoid revenue predation from the Center (Qian \& Weingast, 1997), thus allowing them to retain the financial resources they needed for investments that promoted economic development.

Some studies have, however, offered evidence suggesting that fiscal decentralization fragmented the national market, and hence negatively affected economic growth. Instead of inducing jurisdictional competition that would have potentially enhanced allocative efficiency, decentralization, it is argued, created revenue incentives that encouraged sub-national governments to engage in protectionist behavior (Yang, 1997). Enterprise ownership by local governments provided an incentive to local governments to duplicate enterprises under their jurisdiction so as to capture the revenues that would have otherwise gone to the central coffers, leading to "backward specialization", 2 as evidenced by the convergence of regional relative outputs and a divergence of regional relative factor allocations and labor productivities during the reform era (Young, 2000). As a result, the centrally controlled planned economy devolved, according to this argument, into one of many regional planned economies controlled by sub-national governments (Young, 2000). In addition, such ownership structure of SOEs enabled sub-national governments increasingly to mandate these firms to provide public goods - such as housing, healthcare, childcare, schooling and pension. Thus, it is argued that budget constraint on sub-national governments was effectively

\footnotetext{
${ }^{1}$ Under fiscal contract system, each subnational government level contracted with the next level up to meet certain revenue remittance targets, which could be either a nominal amount or a percentage share. The retention was at the sole discretion of subnational governments. For details, see Bahl and Wallich (1992), World Bank (1989, 1993).

2 The term is used by Yang (1997).
} 
softened by fiscal decentralization, since many local SOEs shared the spending responsibilities of local governments and became de facto government agencies and conduits for central-local financial transfers (Steinfeld, 1999).

The aim of this paper is to attempt to resolve and reconcile these outstanding issues, as well as to relate the Chinese experience to the orthodox theory of fiscal decentralization. Using panel dataset for 30 provinces from 1979 to $1993^{3}$ and 1994 to 1999 , respectively, this paper investigates the relationship between the prevailing fiscal patterns, defined by both expenditure as well as revenue decentralization at the provincial level, and China's provincial economic growth. It further examines how the shift from the contracted revenue sharing (1980-1993) to tax assignment system (1994-1999) affected the relationship between fiscal decentralization and provincial economic growth. It aims to explain how intergovernmental fiscal relations under the two tax regimes affected growth.

Section 2 reviews the theoretical arguments and empirical studies on the relationship between fiscal decentralization and economic growth. Section 3 outlines the hypothesis, explanatory variables, and methodology used in this case study of fiscal decentralization in China. Section 4 reports the regression results and Section 5 summarizes the findings and conclusions.

\section{Literature review}

\subsection{Theoretical considerations}

It has long been held that, in theory, fiscal decentralization may be conducive to economic growth. If few public goods entail nationwide externalities, sub-national governments are likely to be more efficient in the production and delivery of public goods (Oates, 1972). It is also asserted that decision-making on expenditures at lower levels of government is more responsive to diversified local preferences and needs and, therefore, more conducive to allocative efficiency (Oates, 1972; Tiebout, 1956). Decentralizing revenue discretion to sub-national governments to match the spending assignments may also enhance accountability (Oates, 1972). It is held, therefore, that for a given level of government, revenue means should match expenditure needs as closely as possible, thereby (1) stimulating revenue mobilization from local sources, and improving a country's overall fiscal position; (2) improving accountability of sub-national governments; and (3) reducing the distorting effects of intergovernmental transfers (Shah, 1994).

Theorists of fiscal decentralization were inspired, for the most part, by their observations of the functioning of fiscal systems based in highly developed economies, like the United States (Brueckner, 2000). The implications of fiscal decentralization in the context of a developing country are, however, subject to various qualifications due to the divergence between the assumptions of orthodox theory and the institutional as well as economic realities in developing countries. As many have argued, if the standard assumptions of decentralization theory do not hold, the outcomes of fiscal decentralization may be detrimental to economic growth and efficiency (Oates, 1993; Prud'homme, 1995; Tanzi, 1996; Jin and Zou, 2003).

Prud'homme (1995) stresses, for example, that local provision of public goods may not be more cost-effective than at the national level because of economies of scale and economies of scope. It has also been suggested that assuming constituents universally can express their

\footnotetext{
${ }^{3}$ Fiscal contracts between the Center and provinces were gradually introduced in 1980 . This empirical study employed all available time series data since 1979 .
} 
preferences in their votes ignores (1) the patron-client relationships that define the local electoral behavior in developing countries, and (2) the usually vague and inconsistent electoral mandate of local elections in these countries (Prud'homme, 1995). In addition, even if local constituents can express preferences in their votes, and the elected officials want to satisfy the voters' needs, local bureaucracies that carry out the electoral mandate may be poorly motivated and/or qualified to carryout their responsibilities (Prud'homme, 1995).

Fiscal decentralization may also be conducive to corruption at local level because it confers discretion on local politicians and bureaucrats who are more susceptible and accessible to the demands of local interest groups (Prud'homme, 1995; Tanzi, 1996). Corruption at sub-national levels is likely to diminish, if not negate, the benefits that theory suggests fiscal decentralization brings to allocative efficiency and growth.

Moreover, in a non-democratic political system, the basic premise that sub-national governments have a stronger incentive to provided local public goods more efficiently may not apply (Tanzi, 1996). The principle-agent problem in a non-democratic political system may render fiscal decentralization as a tool to be used by sub-national authorities to exploit local constituents and the national treasury (for the case of China, please refer to Wong, 1991; Bahl \& Wallich, 1992; Bahl, 1999).

\subsection{Empirical evidence}

The problem with the recent empirical studies can be summarized from the perspectives of (1) measurements of fiscal decentralization; (2) the relative relationship between expenditure and revenue decentralization; and (3) levels of government. Firstly, using expenditure shares alone to measure decentralization tends to produce a negative (for developing countries) or insignificant (for industrial countries) relationship between fiscal decentralization and economic growth (Davoodi \& Zou, 1998; Xie, Zou, \& Davoodi, 1999; Zhang \& Zou, 1998). ${ }^{4}$ Using revenue shares alone to measure decentralization tends to give results suggesting a positive relationship with economic growth (Ebel \& Yilmaz, 2001). What accounts for these fundamentally contradictory results? Perhaps the most important explanation is that expenditure in most of the countries is typically far more decentralized than revenue. For example, for the six-country sample data for 1999 used in Ebel and Yilmaz (2001), the mean of sub-national expenditure share in total government revenue is $22 \%$, while the mean of sub-national own-taxes revenue share in total government revenue is only $6.2 \%$. Since sub-national governments' own-taxes revenue share in total revenue is substantially lower than their expenditure share in total expenditure, it is therefore not surprising that using revenue shares alone to measure decentralization tends to give results to suggest that revenue decentralization (i.e., increasing the share of sub-national tax revenue share in total government revenue to meet the much larger spending assignments at the corresponding level) promotes economic growth. As such, neither the positive association between revenue decentralization and economic growth found in the study by Ebel and Yilmaz (2001) can undermine or refute the negative (or insignificant) findings between expenditure decentralization and growth found by Davoodi and Zou (1998), Xie et al. (1999), Zhang and Zou (1998), nor vice versa. Because the later use the expenditure shares, which are much more decentralized than revenue shares to assess the relationship between fiscal decentralization and economic growth,

\footnotetext{
${ }^{4}$ Davoodi and Zou (1998) is a cross-country study, while Xie et al. (1999) is a case study on the US and Zhang and Zou (1998) is a case study on China.
} 
and both studies consider only half of the story. Clearly what is necessary in analyzing the relationship between fiscal decentralization and economic growth is to test simultaneously the effect of the level of both expenditure and revenue decentralization, and the effect of the fiscal pattern they hence reveal (i.e., the extent to which expenditure and revenue decentralization converge or diverge), which is the approach taken in this case study of China. What should be note here is that such observations do not imply to detect the optimal level of expenditure or revenue decentralization, but about which directions they move. If the regression suggests that one should move closer to the other, then I call it a convergence. Otherwise divergence.

A second general observation on the recent empirical investigations is that when both decentralization measures are used, the results should be interpreted with respect not just to the coefficients of each measure but should also take into account the decentralization on the two sides of the government budget. In other words, the relationship between expenditure and revenue decentralization matters. For example, Akai and Sakata (2002) use both state expenditure and revenue share in total to proxy for fiscal decentralization. They conclude that "fiscal decentralization contributes to economic growth" because expenditure decentralization has a positive association with state GDP per capita growth rate in all equations. But a comparison of the relative levels of expenditure and revenue decentralization at US state level suggests a different conclusion. Specifically, since expenditure is $7.5 \%$ more decentralized than revenue at the US state level (see Table 3.A.2 in Akai \& Sakata, 2002), to suggest that further expenditure decentralization promotes growth is to imply that expenditure and revenue assignments should diverge, rather than converge as the theoretical literature suggests is conducive to efficiency and growth.

Jin and Zou's (1999) study, using both revenue and expenditure decentralization measures at both state/provincial and local levels ${ }^{5}$ find that a convergence of revenue and expenditure at state/ provincial level and a divergence of them at local level promote growth. The finding that growth is promoted by the convergence of expenditure and revenue at the state/provincial level is consistent with the theoretical principle of fiscal federalism. However, the suggestion for divergence of the two - more expenditure assignments and fewer revenue assignments - at local level is not. The intuitive appeal of this result is that tax bases tend to be smaller and narrower at the local level than at the state/provincial level (Bird, 1992; Mello, 2000). Local governments simply do not have the social and economic endowments to generate the revenue required to finance their spending requirements.

The previous point leads to a third general observation: Most countries have three or more than three levels of government (federal, state and local), however the assignments of expenditure and revenue may have different implications at different sub-national levels of government (e.g., state or local). The question is, however, whether the results for one level of government can be generalized to another. It is well established, for example, that the revenue-generation capacity varies at different levels of government (Musgrave, 1983). The tax bases of local governments (vis-à-vis state/provincial level) are relatively narrow because of possible tax export, externalities in the public goods provision, factor mobility, and economies of scale (Mello, 2000). As such, decentralization of revenue assignments to match local expenditure assignments may not be efficient or growth promoting, as demonstrated in Jin and Zou (1999).

Finally, it is worth recalling that cross-country studies have the disadvantage of pooling countries with substantial differences in history, politics, institutions, and culture, which if not

\footnotetext{
${ }^{5}$ A sample of 11 countries, 1970-1994.
} 
taken into account in the analysis are likely to blur the true relationship between fiscal decentralization and growth (Akai \& Sakata, 2002). Specific country studies, such as the present one, avoid this problem, though it may be argued that their results are less generalizable.

\section{Hypothesis, explanatory variables and methodology}

\subsection{Hypothesis and explanatory variables}

This study uses Chinese provincial panel data for two time periods, 1979-1993 and 19941999, to investigate the effect of fiscal reforms on provincial economic growth under the two fiscal regimes: the fiscal contract system and the tax assignment regime. The purpose of using two time periods is to focus on the effect of the policy change of tax structure and collection that brought by the 1994 reform. Therefore, instead of using tests of structural change to identify the break of time period, the second period is assigned from 1994, the year when the new tax assignment implemented with the split of tax collection between the Center and the provinces.

Fiscal decentralization is measured with respect to both expenditure and revenue assignments. Four fiscal decentralization measures are used. The two measures of expenditure decentralization are (1) provincial budgetary expenditure as a share in total budgetary expenditure, and (2) provincial extra-budgetary expenditure as a share in total extra-budgetary expenditure. The two measures of revenue decentralization are (1) provincial budgetary revenue as a share in total budgetary revenue, and (2) provincial extra-budgetary revenue as a share in total extra-budgetary revenue. Both provincial expenditure and revenue are expenditures spent and revenue collected at the provincial level. Using revenue collected at the provincial level as a share in total revenue to proxy the degree of revenue decentralization has the advantage of incorporating the tax collection aspect. More specifically, since China had a completely localized tax administration during the fiscal contract phase (1979-1993) - i.e., provinces collected taxes for the central government as its agents - provincial revenue share in total revenue should be, on average, larger than provincial expenditure share, the difference being the provinces' remittance to the Center (rather than central transfer to states/provinces, as is more typically the case).

The 1994 fiscal reform replaced localized tax administration by disaggregating tax collection into central and sub-national parts, with the central tax administration collecting central and shared taxes and sub-national bureaus collecting local taxes. Since 1995, central to provincial government transfers are recorded in the budget. In addition to the expenditure and revenue decentralization measures, the intergovernmental transfer, measured by central transfer to provinces as a percentage in total provincial expenditure, is taken into account in the analysis for the second phase of the fiscal reform so as to assess the potential distorting effect of such transfers at provincial level.

Conventional fiscal decentralization theory holds that the matching of revenue means and expenditure assignments at sub-national level promotes economic growth. Therefore, the signs on the coefficient of expenditure and revenue decentralization, taking into account the average levels of revenue and expenditure share, should indicate whether convergence or divergence of revenue and expenditure decentralization promotes growth.

Two tax variables are employed to examine the effects of distortion of taxes imposed by central and provincial governments. Tax rates are used as aggregate measures of distortion introduced by governments to finance their spending (Zhang \& Zou, 1998). Specifically, the central tax rate, measured by central tax revenues as a percentage of total GDP, is used to capture the effect of distortion at the national level. The provincial tax rate, measured by provincial 
(collected) tax revenue as a percentage of total provincial GDP, is used to capture the effect of distortion at the provincial level. It is expected that the higher the tax rate, the more the economy is distorted by the fiscal system (Barro, 1990).

While our main interest is the relationship between fiscal decentralization and economic growth, we must acknowledge that economic growth is subject to many influences beyond fiscal decentralization. In order to control for these influences we introduce a set of control variables to improve the robustness of the result. This set of control variables is consistent with the set of variables used in Zhang and Zou's (1998) case study of China, allowing their results to be compared to those presented in this study. The control variables used in this study includes: Physical and human capital investments, respectively measured by (1) the sum of gross investment (government and enterprises together) as a share in GDP at provincial level and (2) the growth rate of the provincial labor force.

Another important determinant of growth is openness to international trade, which is measured by the ratio of imports plus exports to GDP at provincial level. It is conventional to hypothesize a positive relation between openness and growth on grounds that international competition improves resource allocation via exports and more advance technology from industrial countries can be attained via imports (Feder, 1983 quoted in Zhang \& Zou, 1998).

Finally, we allow for the potential effect of macroeconomic instability on economic growth, using the lagged inflation rate at the provincial level as a proxy for this variable. Inflation can have both a positive and negative effect on growth. The positive effect stems from the potential for inflation to promote savings and investment, as agents shift from financial wealth (money) to real assets (capital) to avoid the deleterious effects of inflation on real money balances (the Tobin portfolio-shift effect). On the other hand, inflation may dampen economic growth because it raises the transaction cost of economic activities (Zhang \& Zou, 1998).

Data sources. The pre-1990 data are taken from Hseh, Li, and Liu (1993). ${ }^{6}$ The post 1989 data for the 30 provinces $^{7}$ are from the China Finance Statistical Yearbook (various issues) and the China Statistical Yearbook (various issues). The panel datasets for thirty provinces cover 19791993 and 1994-1999 separately (using the same methodology for these two time periods).

A statistical summary of the key variables. Table 1 provides the statistics of annual budgetary expenditure and revenue shares in total government budgetary items across all provinces.

As indicated in Table 1, revenue is more decentralized than expenditure in every year. ${ }^{8}$ The difference between the expenditure and revenue shares was the provincial remittance to the Center. After introducing the fiscal contract system in 1980, the degree of revenue decentralization (averaged provincial revenue collection share in total government revenue) decreased from $2.6 \%$ in 1980 to $2.0 \%$ in 1985 while the degree of expenditure decentralization (averaged provincial

\footnotetext{
${ }^{6}$ Hseh, Tien-tung, Li, Qiang, and Liu, Shucheng (Eds.), 1993. China's Provincial Statistics 1949-89. Boulder: Westview Press.

${ }^{7}$ Chongqing became a direct municipal city in 1997. Since it is hard to disaggregate the statistics of Chongqing from that of Sichuan province before 1997, Chongqing's statistics are added back to that of Sichuan for the years after 1997.

${ }^{8}$ Since the statistics in Table 1 are the means of each province's revenue and expenditure share in total. The mean discrepancy between revenue (2.4\%) and expenditure decentralization (1.9\%) therefore represents the share of a single province's revenue/expenditure in total government revenue/expenditure. To acquire an idea of the discrepancy between revenue and expenditure decentralization between central and provincial governments aggregated, the statistics in Table 1 should be multiplied by 29 , which is the number of provinces (Tibet was dropped). For example, the discrepancy of revenue and expenditure decentralization between the Center and provincial level of government is average at $(2.4-1.9) \times 29=14.5 \%$.
} 
Table 1

Fiscal decentralization by year (1979-1993)

\begin{tabular}{|c|c|c|c|c|c|c|c|c|c|c|c|c|c|}
\hline \multicolumn{7}{|c|}{ Expenditure decentralization by year (1979-1993) } & \multicolumn{7}{|c|}{ Revenue decentralization by year (1979-1993) } \\
\hline Year & $\mathrm{Obs}^{\mathrm{a}}$ & Mean & S.D. & Min & Max & $\begin{array}{l}\text { Coefficient } \\
\text { of variation }\end{array}$ & Year & Obs & Mean & S.D. & Min & Max & $\begin{array}{l}\text { Coefficient } \\
\text { of variation }\end{array}$ \\
\hline 1979 & 29 & 1.7 & 0.7 & 0.1 & 2.9 & 0.41 & 1979 & 29 & 2.7 & 3.0 & 0.1 & 15.1 & 1.09 \\
\hline 1980 & 29 & 1.6 & 0.7 & 0.2 & 2.8 & 0.41 & 1980 & 29 & 2.6 & 3.0 & 0.1 & 15.1 & 1.14 \\
\hline 1981 & 29 & 1.6 & 0.6 & 0.2 & 2.7 & 0.39 & 1981 & 29 & 2.5 & 2.9 & 0.1 & 14.8 & 1.15 \\
\hline 1982 & 29 & 1.7 & 0.7 & 0.2 & 2.8 & 0.38 & 1982 & 29 & 2.5 & 2.7 & 0.1 & 13.9 & 1.10 \\
\hline 1983 & 29 & 1.7 & 0.6 & 0.2 & 2.8 & 0.37 & 1983 & 29 & 2.2 & 2.2 & 0.1 & 11.4 & 1.01 \\
\hline 1984 & 29 & 1.8 & 0.7 & 0.3 & 3.1 & 0.36 & 1984 & 29 & 2.0 & 2.0 & 0.1 & 10.0 & 0.96 \\
\hline 1985 & 29 & 1.9 & 0.8 & 0.2 & 3.5 & 0.40 & 1985 & 29 & 2.0 & 1.8 & 0.1 & 9.2 & 0.89 \\
\hline 1986 & 29 & 2.0 & 0.8 & 0.3 & 3.8 & 0.42 & 1986 & 29 & 2.2 & 1.7 & 0.1 & 8.5 & 0.81 \\
\hline 1987 & 29 & 2.0 & 0.9 & 0.3 & 3.7 & 0.43 & 1987 & 29 & 2.3 & 1.7 & 0.1 & 7.7 & 0.73 \\
\hline 1988 & 29 & 2.1 & 0.9 & 0.3 & 4.3 & 0.45 & 1988 & 29 & 2.3 & 1.6 & 0.2 & 6.9 & 0.68 \\
\hline 1989 & 29 & 2.2 & 1.0 & 0.5 & 4.6 & 0.47 & 1989 & 29 & 2.4 & 1.6 & 0.2 & 6.3 & 0.64 \\
\hline 1990 & 29 & 2.1 & 1.0 & 0.4 & 4.4 & 0.47 & 1990 & 29 & 2.3 & 1.4 & 0.2 & 5.8 & 0.62 \\
\hline 1991 & 29 & 2.2 & 1.1 & 0.5 & 4.8 & 0.49 & 1991 & 29 & 2.5 & 1.5 & 0.2 & 5.6 & 0.61 \\
\hline 1992 & 29 & 2.0 & 1.0 & 0.4 & 5.0 & 0.50 & 1992 & 29 & 2.4 & 1.5 & 0.2 & 6.4 & 0.63 \\
\hline \multirow[t]{2}{*}{1993} & 29 & 2.2 & 1.2 & 0.4 & 6.3 & 0.58 & 1993 & 29 & 2.6 & 1.8 & 0.2 & 8.0 & 0.72 \\
\hline & & 1.9 & 0.8 & 0.3 & 3.8 & & & & 2.4 & 2.0 & 0.2 & 9.6 & \\
\hline
\end{tabular}

a Tibet is dropped due to unavailability of data.

expenditure share in total government expenditure) increased from $1.6 \%$ in 1980 to $1.9 \%$ in 1985 . As a result, the gap between the average expenditure decentralization (across provinces) and revenue decentralization gradually narrowed.

After 1985, expenditure decentralization varied between 2.0 and $2.2 \%$ while revenue decentralization also started to increase from $2.0 \%$ in 1985 to $2.6 \%$ in 1993 . As a result, the gap between revenue and expenditure assignments at provincial level steadily widened.

The relative change between expenditure and revenue decentralization across the first phase is also captured in Fig. 1.

In addition, the coefficients of variation of expenditure decentralization increased slightly from around 0.41 in the first half of 1980 s to 0.58 in 1993 (Table 1 and Fig. 1). At the same time, the coefficients of variation of revenue decentralization decreased dramatically from 1.15 in 1981 to 0.61 in 1991 and then increased slightly to 0.72 in 1993 . In other words, the degree of revenue decentralization across provinces converged through the 1980s. Such a convergence, in the context of a decreased revenue decentralization level (mean across provinces, as show by the decreasing mean statistic of the annual revenue decentralization across provinces shown in Fig. 1) in the first half of 1980s, indicates that the relatively wealthier provinces, with their lever of controlling tax collection, relaxed their revenue collections (to avoid sharing with the Center), hence their revenue decentralization level converged to the lower levels of the poorer ones. ${ }^{9}$

\footnotetext{
${ }^{9}$ The coefficient of variation of revenue decentralization is the ratio of standard deviation of revenue decentralization across provinces divided by the mean of cross-province revenue decentralization. As the mean statistic (in the denominator) decreased before 1985, the standard deviation (in the numerator) decreased by more than the mean to yield a decreasing coefficient of variation. As such, the dispersion of revenue decentralization reduced significantly-i.e., the high degree of revenue decentralization of better off provinces reduced and converged to the lower level of revenue decentralization of poorer provinces.
} 


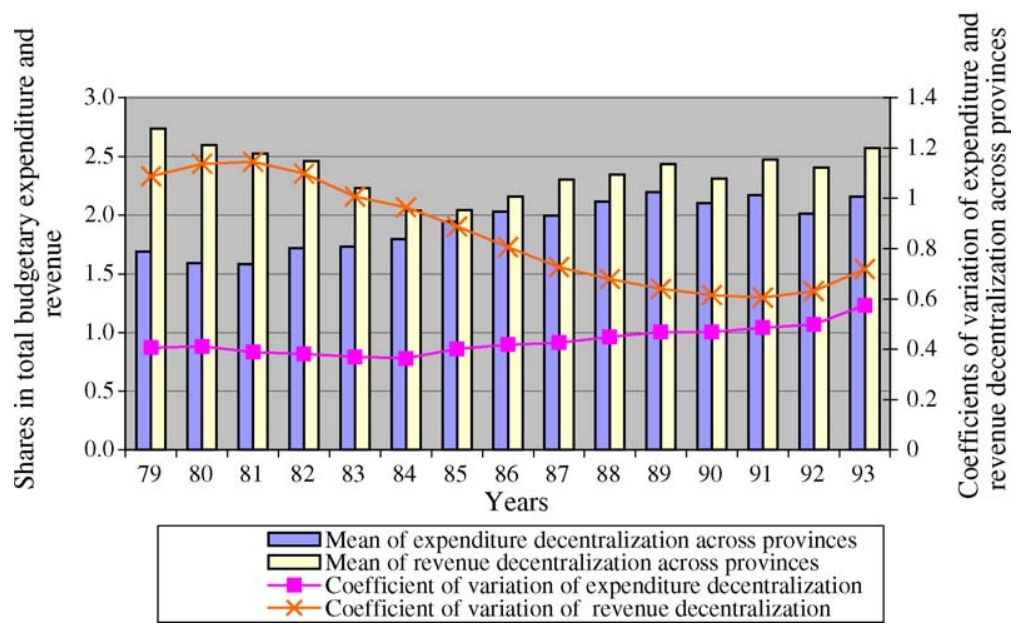

Fig. 1. Budgetary expenditure and revenue decentralization (1979-1993).

Furthermore, as noted before, the difference between expenditure and revenue decentralization is the provincial remittance to the Center. It is shown by the difference between revenue decentralization (white bars) and expenditure decentralization (darker bars) in Fig. 1. As demonstrated in Fig. 1, the provincial remittance to the Center (the excess part of white bars over darker bars) gradually declined since the implementation of fiscal contracts as the excess part of revenue over expenditure decentralization decreased.

From 1986 to 1991 , the shares of provincial revenue in total government revenue further converged across provinces as shown by the further decrease of coefficient of variation of revenue decentralization. Table 1 shows that this is a result of a further decline in standard deviation of revenue decentralization across provinces at the time when the mean level of revenue decentralization increased. Such a convergence can be a result of either (1) the revenue collection of poor provinces grew faster than that of the wealthier provinces, or (2) the revenue collection of wealthier provinces grew relatively slowly because the contract regime incited them to engage in strategies that enabled them to accrue more of the revenue increments within their own jurisdictions (For details, see Wong, 1991; Bahl \& Wallich, 1992; and Bahl, 1999), or both.

The coefficient of variation of revenue decentralization increased slightly in 1992 and sharply in 1993. The increase in 1992 was a result of the reduced cross-province mean of revenue decentralization (while the standard deviation was constant at 1991 level). The jump in 1993, however, was a result of an increase in the mean and a larger increase of standard deviation of revenue decentralization cross provinces. Such a change in 1993 was to a large extent a function of the design of 1994 fiscal reform. More specifically, the compromised plan of 1994 fiscal reform, under which provincial income level of 1994 was ensured by central "tax refund" up to their 1993 level, stimulated a sudden inflation of provincial revenue collection. Provinces thus attempted to boost the baseline of 1993 in order to entitle more "tax refund" from the Center in 1994 (for details, see Wang, 1997). Since wealthier provinces now switched strategy from hiding revenues to exhausting tax collections, this dramatically increased the dispersion in revenue decentralization across provinces.

Table 2 provides the statistics of annual budgetary expenditure and revenue share (mean across all provinces) in total government budgetary items during 1994-1999. Revenue 
Table 2

Fiscal decentralization by year (1994-1999)

\begin{tabular}{|c|c|c|c|c|c|c|c|c|c|c|c|c|c|}
\hline \multicolumn{7}{|c|}{ Expenditure decentralization by year (1994-1999) } & \multicolumn{7}{|c|}{ Revenue decentralization by year (1994-1999) } \\
\hline Year & Obs & Mean & S.D. & Min & Max & $\begin{array}{l}\text { Coefficient } \\
\text { of variation }\end{array}$ & Year & Obs & Mean & S.D. & Min & Max & $\begin{array}{l}\text { Coefficient } \\
\text { of variation }\end{array}$ \\
\hline 1994 & 29 & 2.4 & 1.4 & 0.3 & 7.2 & 1.52 & 1994 & 29 & 1.5 & 1.2 & 0.1 & 5.7 & 0.76 \\
\hline 1995 & 30 & 2.4 & 1.5 & 0.3 & 7.7 & 1.60 & 1995 & 30 & 1.6 & 1.2 & 0.1 & 6.1 & 0.76 \\
\hline 1996 & 30 & 2.4 & 1.5 & 0.4 & 7.6 & 1.69 & 1996 & 30 & 1.7 & 1.3 & 0.0 & 6.5 & 0.78 \\
\hline 1997 & 30 & 2.4 & 1.5 & 0.4 & 7.4 & 1.64 & 1997 & 30 & 1.6 & 1.3 & 0.0 & 6.3 & 0.79 \\
\hline 1998 & 30 & 2.4 & 1.5 & 0.4 & 7.6 & 1.68 & 1998 & 30 & 1.7 & 1.3 & 0.0 & 6.5 & 0.80 \\
\hline \multirow[t]{2}{*}{1999} & 30 & 2.3 & 1.4 & 0.4 & 7.3 & 1.63 & 1999 & 30 & 1.6 & 1.4 & 0.0 & 6.7 & 0.83 \\
\hline & & 2.4 & 1.5 & 0.4 & 7.5 & & & & 1.6 & 1.3 & 0.1 & 6.3 & \\
\hline
\end{tabular}

decentralization, which measured by the tax revenue collected at provincial level as a share in total revenue, therefore largely reduced. Now the degree of revenue and expenditure decentralization at the provincial level is reversed vis-à-vis the first phase of fiscal reformunlike in the first phase, expenditure became more decentralized than revenue, with the average cross-province shares stabilized around 2.4 and 1.6\%, respectively (Table 2). The gap, instead of representing provincial remittance to the Center, now reflects the Central transfer to the provinces.

\subsection{Methodology}

First, the regression analysis in this study uses the panel data econometric technique. Panel data sets combine time series and cross sections. They allow more flexibility in modeling. Time series data for each province in this cross-province regression analysis can better capture the dynamics of the relationship between fiscal decentralization and provincial economic growth. Second, all coefficients are estimated with fixed-effects with corrections for panel heteroskedasticity and panel serial correlation.

Using the panel data of 30 provinces, 1979-1993 and 1994-1999 separately, the following model is employed to examine how fiscal decentralization affects provincial growth:

$$
\text { GDPgrowth }_{i, t}=\alpha_{0}+\alpha_{1} \text { FD }_{i, t}+\alpha_{2} \text { TAX }_{i, t}+\alpha_{3} \text { POLITICAL }_{i, t}+\alpha_{4} \text { CONTROL }_{i, t}+\varepsilon_{i, t}
$$

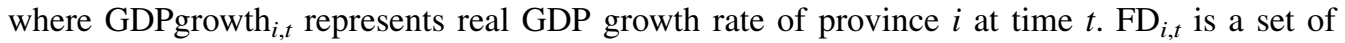
vectors of fiscal decentralization measuring expenditure decentralization, revenue decentralization (both further disaggregated into budgetary and extra-budgetary terms), and intergovernmental transfers when applied to the time period of $1994-1999$. TAX $_{i, t}$ is a set of vectors measuring the distorting effects of tax at both central and provincial level—central and provincial tax rates.

CONTROL $_{i, t}$ is a set of variables that control for provincial investment, labor force growth rate, the level of openness and provincial inflation (lagged).

\section{Regression results}

Table 3 reports the fixed- and random-effect results of how fiscal decentralization affected provincial economic reform for the time period 1979-1993. Table 4 reports the fixed and randomeffect results for the time period 1994-1999. 
Table 3

Fixed effects 1979-1993

\begin{tabular}{|c|c|c|c|c|c|c|c|}
\hline \multirow[t]{2}{*}{ Dependent variable } & \multicolumn{7}{|c|}{ Provincial real GDP growth rate } \\
\hline & $\begin{array}{l}1^{\mathrm{a}} \\
\text { Coefficients } \\
(1979-1993)\end{array}$ & $\begin{array}{l}2^{\mathrm{a}} \\
\text { Coefficients } \\
(1979-1993)\end{array}$ & $\begin{array}{l}3^{\mathrm{a}} \\
\text { Coefficients } \\
(1979-1993)\end{array}$ & $\begin{array}{l}4^{\mathrm{a}} \\
\text { Coefficients } \\
(1982-1992)\end{array}$ & $\begin{array}{l}5^{\mathrm{a}} \\
\text { Coefficients } \\
(1982-1992)\end{array}$ & $\begin{array}{l}6^{\mathrm{a}} \\
\text { Coefficients } \\
(1982-1992)\end{array}$ & $\begin{array}{l}7^{\mathrm{a}} \\
\text { Coefficients } \\
(1982-1992)\end{array}$ \\
\hline Central tax rate & $0.79(3.47)^{* * *}$ & $0.80(3.43)^{\text {*** }}$ & $0.88(3.83)^{* * * *}$ & $0.97(4.05)^{* * *}$ & $0.96(3.81)^{* *}$ & $1.10(4.60)^{* * * *}$ & $1.21(4.80)^{* * *}$ \\
\hline Provincial tax rate & $0.02(0.28)$ & $-0.12(-0.94)$ & $-0.21(-1.66)^{*}$ & $-0.04(-0.43)$ & $-0.04(-0.43)$ & $-0.33(-1.95)^{*}$ & $-0.24(-1.33)$ \\
\hline $\begin{array}{l}\text { Expenditure decentralization } \\
\text { (budgetary) }\end{array}$ & $-2.89(-3.11)^{* * *}$ & & $-3.63(-3.68)^{* * *}$ & & & $-5.53(-4.36)^{* * * *}$ & $-6.29(-4.54)^{* * * *}$ \\
\hline $\begin{array}{l}\text { Revenue decentralization } \\
\text { (budgetary) }\end{array}$ & & $0.54(0.98)$ & $1.25(2.19)^{* *}$ & & & $2.01(2.50)^{* *}$ & $1.57(1.81)^{*}$ \\
\hline $\begin{array}{l}\text { Expenditure decentralization } \\
\text { (extra-budgetary) }\end{array}$ & & & & $-0.39(-0.28)$ & & $0.86(0.61)$ & $-0.91(-0.47)$ \\
\hline $\begin{array}{l}\text { Revenue decentralization } \\
\text { (extra-budgetary) }\end{array}$ & & & & & $-0.14(-0.13)$ & & $2.43(1.35)$ \\
\hline Labor growth rate & $0.21(1.15)$ & $0.24(1.30)$ & $0.21(1.13)$ & $0.47(2.26)^{* *}$ & $0.47(2.24)^{* *}$ & $0.46(2.30)^{* *}$ & $0.49(2.42)^{* *}$ \\
\hline Investment rate & $0.26(4.60)^{* * *}$ & $0.22(3.90)^{* * * *}$ & $0.26(4.64)^{* * *}$ & $0.09(1.37)$ & $0.10(1.35)$ & $0.15(2.25)^{* *}$ & $0.11(1.53)$ \\
\hline Openness & $0.09(1.49)$ & $-7.97 \mathrm{E}-03(-0.14)$ & $0.09(1.41)$ & $0.08(1.07)$ & $0.08(1.04)$ & $0.17(2.32)^{* *}$ & $0.17(2.28)^{* *}$ \\
\hline Provincial inflation (lagged) & $2.85(2.41)^{* *}$ & $2.62(2.17)^{* *}$ & $2.48(2.09)^{* *}$ & $1.16(0.89)$ & $1.18(0.90)$ & $0.71(0.56)$ & $0.70(0.55)$ \\
\hline Constant & $-2.04(-0.63)$ & $-4.94(-1.59)$ & $-0.57(-0.17)$ & $-1.36(-0.31)$ & $-1.81(-0.45)$ & $4.07(0.92)$ & $4.26(0.97)$ \\
\hline Number of observations & 383 & 383 & 383 & 303 & 303 & 303 & 303 \\
\hline Number of groups & 28 & 28 & 28 & 28 & 28 & 28 & 28 \\
\hline$R^{2}$ within & 0.15 & 0.13 & 0.16 & 0.13 & 0.13 & 0.19 & 0.194 \\
\hline$R^{2}$ between & 0.06 & 0.03 & 0.01 & 0.09 & 0.12 & 0.00 & 0.004 \\
\hline$R^{2}$ overall & 0.02 & 0.11 & 0.05 & 0.12 & 0.12 & 0.05 & 0.042 \\
\hline
\end{tabular}

Note: The number in parentheses represents the $t$-statistic associated with each coefficient.

${ }^{a}$ Independent variables.

* Indicates a significance level at $10 \%$.

* Indicates a significance level at $5 \%$.

*** Indicates a significance level at $1 \%$. 
Table 4

Fixed effects 1994-1999

\begin{tabular}{|c|c|c|c|c|c|c|c|}
\hline \multirow[t]{2}{*}{ Dependent variable } & \multicolumn{7}{|c|}{ Provincial real GDP growth rate } \\
\hline & $\begin{array}{l}1^{\mathrm{a}} \\
\text { Coefficients } \\
(1994-1999)\end{array}$ & $\begin{array}{l}2^{\mathrm{a}} \\
\text { Coefficients } \\
(1994-1999)\end{array}$ & $\begin{array}{l}3^{\mathrm{a}} \\
\text { Coefficients } \\
(1995-1999)\end{array}$ & $\begin{array}{l}4^{\mathrm{a}} \\
\text { Coefficients } \\
(1995-1999)\end{array}$ & $\begin{array}{l}5^{\mathrm{a}} \\
\text { Coefficients } \\
(1995-1999)\end{array}$ & $\begin{array}{l}6^{\mathrm{a}} \\
\text { Coefficients } \\
(1994-1998)\end{array}$ & $\begin{array}{l}7^{\mathrm{a}} \\
\text { Coefficients } \\
(1994-1998)\end{array}$ \\
\hline Central tax rate & $-1.10(-3.68)^{* * * *}$ & $-1.06(-4.07)^{* * * *}$ & $-1.43(-4.10)^{* * * *}$ & $-1.40(-3.55)^{* * * *}$ & $-1.32(-3.78)^{* * *}$ & $-1.03(-1.98)^{*}$ & $-0.97(-1.87)^{*}$ \\
\hline Provincial tax rate & $0.43(1.26)$ & $0.44(1.44)$ & $0.50(1.25)$ & $0.59(1.33)$ & $0.61(1.51)$ & $0.39(0.92)$ & $0.41(0.97)$ \\
\hline $\begin{array}{l}\text { Expenditure decentralization } \\
\text { (budgetary) }\end{array}$ & $-1.06(-1.00)$ & & & $0.16(0.13)$ & $0.75(0.58)$ & $-1.08(-0.90)$ & $-1.18(-0.98)$ \\
\hline $\begin{array}{l}\text { Revenue decentralization } \\
\text { (budgetary) }\end{array}$ & & $-0.51(-2.61)^{* * *}$ & & $-0.36(-2.19)^{* *}$ & $-0.33(-2.01)^{* *}$ & $-0.49(-2.39)^{* *}$ & $-0.49(-2.39)^{* *}$ \\
\hline Central transfer & & & $0.01(0.26)$ & $0.00(-0.02)$ & & & \\
\hline Provincial remittance & & & & & $0.06(1.28)$ & & \\
\hline $\begin{array}{l}\text { Expenditure decentralization } \\
\text { (extra-budgetary) }\end{array}$ & & & & & & $-0.92(-1.26)$ & \\
\hline $\begin{array}{l}\text { Revenue decentralization } \\
\text { (extra-budgetary) }\end{array}$ & & & & & & & $-0.67(-1.01)$ \\
\hline Labor growth rate & $0.09(1.45)$ & $0.11(1.74)^{*}$ & $0.09(1.58)$ & $0.09(1.71)^{*}$ & $0.10(1.79)^{*}$ & $0.13(1.66)^{*}$ & $0.12(1.60)$ \\
\hline Investment rate & $0.12(2.74)^{* * *}$ & $0.12(2.76)^{* * * *}$ & $0.06(1.23)$ & $0.07(1.42)$ & $0.03(0.69)$ & $0.10(1.81)^{*}$ & $0.11(1.84)^{*}$ \\
\hline Openness & $0.01(0.58)$ & $0.01(0.70)$ & $0.00(0.18)$ & $0.01(0.29)$ & $0.01(0.28)$ & $0.01(0.54)$ & $0.01(0.53)$ \\
\hline Provincial inflation (lagged) & $-2.27(-7.83)^{* * *}$ & $-2.27(-8.10)^{* * *}$ & $-1.59(-3.68)^{* * *}$ & $-1.77(-4.06)^{* * *}$ & $-1.47(-3.52)^{* * *}$ & $-2.01(-5.90)^{* * *}$ & $-2.06(-6.13)^{* * *}$ \\
\hline Constant & $20.99(6.05)^{* * *}$ & $18.92(9.47)^{* * *}$ & $19.19(7.36)^{* * * *}$ & $19.60(4.82)^{* * *}$ & $16.77(3.93)^{* * *}$ & $22.39(4.61)^{* * *}$ & $22.09(4.52)^{* * * *}$ \\
\hline Number of observations & 167 & 167 & 139 & 139 & 139 & 139 & 139 \\
\hline Number of groups & 28 & 28 & 28 & 28 & 28 & 28 & 28 \\
\hline$R^{2}$ within & 0.5812 & 0.5987 & 0.6073 & 0.6251 & 0.631 & 0.5361 & 0.5335 \\
\hline$R^{2}$ between & 0.0767 & 0.0261 & 0.0183 & 0.026 & 0.0465 & 0.1634 & 0.1612 \\
\hline$R^{2}$ overall & 0.0737 & 0.1516 & 0.1965 & 0.1661 & 0.26 & 0.0003 & 0.0002 \\
\hline
\end{tabular}

Note: The number in parentheses represents the $t$-statistic associated with each coefficient.

${ }^{\mathrm{a}}$ Independent variables.

* Indicates a significance level at $10 \%$.

** Indicates a significance level at $5 \%$.

*** Indicates a significance level at $1 \%$ 


\subsection{First phase: 1979-1993}

As Table 3 indicates, provincial economic growth is negatively associated with expenditure decentralization and positively associated with revenue decentralization. That is, further revenue decentralization and expenditure centralization promote growth. The negative association between expenditure decentralization and provincial real GDP growth rate contradicts the conventional wisdom of fiscal decentralization. It is, however, consistent with Zhang and Zou's (1998) result. Hence, their interpretation that "the central government may be in a better position to undertake public investment with nation-wide externalities in the early stages of economic development" is supported by this result. Second, the positive association between revenue decentralization and provincial real GDP growth rate supports the proponents of fiscal decentralization theories. In this case when revenue decentralization is measured by revenue collected at provincial level, this result specifically suggests that assigning more revenue collection to the sub-national levels leads to higher growth, because it stimulates revenue mobilization from local sources and improve overall fiscal position (Shah, 1994). In addition, central tax rate has a significant and consistent positive association with provincial economic growth. This result is counter intuitive, but may be reconciled by the observation that when central government revenue is low, countries are more prone to macroeconomic instability, which may deter growth. (Ahamd, Gao, \& Tanzi, 1995; Yusuf, 1994).

If instead of analyzing expenditure and revenue decentralization along, we compare the results with the mean level of the degree of expenditure and revenue decentralization at China's provincial level, we reach rather different conclusions. Since in this phase, revenue is already on average more decentralized than expenditure (2.4\% versus $1.9 \%$ ), further decentralizing revenue and centralizing expenditure suggests a divergence of expenditure and revenue at provincial level is growth promoting (because further revenue decentralization means a higher share than $2.4 \%$ and further expenditure centralization means a lower share than $1.9 \%$, hence the divergence). Without changing the fiscal contract regime, and assigning more revenue collection and less expenditure responsibilities to the provinces, allowing more revenue to be remitted to the Center appears to promote provincial economic growth.

In other words, provincial governments appear to be efficient in collecting money, while the central government appears to be more efficient in spending it. With an institutional setting of localized tax collection, the fiscal pattern suggested by the regression result, however, is consistent with the implementation of a fiscal contract system between central and provincial governments, under which the central government contracts tax collection out to its regional agents and claim a proportion of total revenue collected.

The control variables perform in the regression very much as expected, with provincial labor growth rate, investment rate, and openness all being positively associated with provincial economic growth. The lagged provincial inflation level also exhibits a positive association with provincial economic growth and the effect is statistically significant at $5 \%$ level when extra-budgetary expenditure and revenue share are absent from the equation (Equations 1, 2, and 3 in Table 3). This is not a surprise for a transition economy like China, which started its economic reform by liberalizing prices sector by sector. In addition, it may also suggest that inflation has a positive effect on growth by spurring investment in physical capital (Tobin portfolio-shift effect), overriding the negative effect of higher transaction costs on growth. 


\subsection{Second phase: $1994-1999$}

The overhaul of the fiscal contract system in 1994 substantially changed the relationship between provincial economic growth and the degree of fiscal decentralization. Table 4 presents the regression results testing the relationship between fiscal decentralization and growth for the period after 1994 when the tax assignment system was applied. Provincial economic growth rate is shown to have no statistically significant association with expenditure decentralization, and is negatively (rather than positively) associated with revenue decentralization, with a high level of consistency and statistical significance.

There is no significant association found between expenditure decentralization and provincial economic growth. Unlike in the earlier phase, revenue centralization is found to be positively associated with provincial economic growth, and the relationship is highly consistent and statistically significant (Table 4). Given that revenue is already more centralized than expenditure (averaged at $2.4 \%$ versus $1.6 \%$ ) after the 1994 tax assignment reform, ${ }^{10}$ further revenue centralization suggests that a divergence of expenditure and revenue at provincial level - which should have implied that more transfers from the Center to provinces - promotes growth. Central transfers, however, are not found to be associated with higher growth in the regression results. A possible explanation lies in the compromise made between the Center and provinces at the onset of implementing tax assignment reform in 1994. That is, since the tax assignment reform would surely largely reduce the revenue collection at the provincial level, wealthier provinces that benefited the most from the contract regime resisted to comply. The Center compromised: for those provinces, whose own revenue would be reduced to lower than their 1993 level under the new tax assignment system, were entitled to a "tax refund" from the central government at a level that would ensure their revenues no lower than the 1993 level. ${ }^{11}$ With an overwhelming proportion of "tax refund" in central transfers that are actually not at the discretion of the Center to serve macroeconomic stability, central transfers is found to have no significant positive association with provincial growth.

The control variables also performed as expected in the second phase. Provincial labor growth rate and investment rate show a positive signs with economic growth, but the association is weaker in both magnitude and statistical significance than in the earlier period. It is perhaps not surprising that physical inputs (investment and labor force growth) played a more significant role in the early years of the transition. However, as China moved into the 1990s, capital accumulation may have led to diminishing returns. Openness, although still positively associated with economic growth, is not a statistically significant explanatory variable in the second era. A possible explanation lies in the export VAT rebate implemented since 1994. Since the rebate falls solely on the central budget, provinces overstate exports in order to obtain more tax rebate. The degree of openness, measured by the total of exports and imports as a percentage in provincial GDP, may therefore be exaggerated.

Lagged provincial inflation, unlike in the first phase, is negatively related with provincial growth and the association is highly consistent and significant (most of the times at $1 \%$

\footnotetext{
$\overline{10}$ The split of central and subnational tax administration substantially increased revenue collected at central level and reduced revenue collected at provincial level, and hence reduced provincial revenue share in total revenue from its average level of $2.4 \%$ (1979-1993) to $1.7 \%$ (1994-1999). At the same time, expenditure were increasingly devolved to subnational levels, hence the degree of expenditure decentralization (provincial expenditure share in total government expenditure) increased from 1.9 in the (1979-1993) to 2.3 (1994-1999).

${ }^{11}$ For details, see Wang (1997).
} 
level) — a sign of the overriding negative effect brought by the rise of transaction costs in the 1990s.

\section{Summary and conclusion}

This study attempts to examine how fiscal decentralization affected provincial economic growth in China. In addition, it investigates how the relationship between fiscal decentralization and provincial growth differed under the two different fiscal regimes that were adopted in China since 1980.

The conventional wisdom that fiscal decentralization - revenue means should match expenditure needs as close as possible at sub-national level - to improves allocative efficiency and promote economic growth does not apply in the case of China. Using a panel data set for China's 30 provinces for the time period from 1979 to 1993 and 1994 to 1999 separately, the results of this study suggest that in both time periods, expenditure and revenue decentralization levels should further diverge to benefit provincial growth.

For the revenue contract system (1979-1993), for example, tax collection was localized and the provinces collected taxes on the Center's behalf as its agents. Revenue decentralization, as measured by tax collection at each province as a percentage in total revenue, was therefore much more decentralized than expenditure because the provinces remitted a proportion (or a fixed amount plus a pre-determined growth rate) of the collected tax revenue to the Center and kept the rest (for detail, see Ahmad et al., 1995; Bahl \& Wallich, 1992; World Bank, 1993). As such, the marginal budgetary revenue collection and marginal budgetary expenditure was highly correlated, and therefore suggests that more revenue decentralization spurs tax collection and allows for more spending (possibly by both central and provincial government) on investment (Jin, Qian, \& Weingast, 1999). While this explanation supports the notion that revenue decentralization stimulates revenue mobilization from local sources (Shah, 1994), it also suggests that expenditure centralization promotes growth because the central government spends more efficiently than the provinces (Zhang \& Zou, 1998).

The tax assignment reform in 1994 changed the tax administration with the establishment of central tax bureaus to collect central and shared-taxes, and sub-national tax bureaus to collect sub-national exclusive taxes. Revenue became more centralized than expenditure, with the expenditure gaps in provinces bridged by central transfers to the provinces. This is a fiscal pattern that is more comparable to other countries. The regression results suggest that at given level of expenditure decentralization, more revenue centralization contributes to growth. This finding supports the view that the Center is in a better position to allocate budgetary resources for horizontal balance, macroeconomic stability, and investment in projects of national significance.

This study adds to a growing body of evidence that under certain circumstances, fiscal decentralization can be detrimental to economic growth (Steinfeld, 1999; Yang, 1997; Young, 2000; Zhang \& Zou, 1998). The results of this study also underscore the fundamental proposition that institution matters. The effects of fiscal decentralization in any given case depend critically on the nature of the fiscal institutions and political system in place.

\section{Acknowledgements}

For comments and suggestion, we are grateful to Eiji Tajika and the participants of International Symposium on Tax Policy and Reform in Asia organized by Hitotsubashi University. We are responsible for all remaining errors. 


\section{Appendix A}

See Tables A.1 and A.2.

Table A.1

Fiscal decentralization by province (1979-1993)

\begin{tabular}{|c|c|c|c|c|c|c|c|c|c|c|c|c|}
\hline & \multicolumn{6}{|c|}{ Expenditure decentralization by province (1979-1993) } & \multicolumn{6}{|c|}{ Revenue decentralization by province (1979-1993) } \\
\hline & Province & Obs & Mean & S.D. & Min & $\operatorname{Max}$ & Provinces & Obs & Mean & S.D. & Min & $\operatorname{Max}$ \\
\hline 1 & Beijing & 15 & 1.7 & 0.2 & 1.2 & 2.0 & Beijing & 15 & 3.1 & 0.8 & 2.0 & 4.5 \\
\hline 2 & Tianjin & 15 & 1.3 & 0.2 & 1.0 & 1.9 & Tianjin & 15 & 2.5 & 0.7 & 1.5 & 3.5 \\
\hline 3 & Hebei & 15 & 2.4 & 0.2 & 2.1 & 2.9 & Hebei & 15 & 2.8 & 0.5 & 2.0 & 4.0 \\
\hline 4 & Shanxi & 15 & 1.7 & 0.2 & 1.4 & 1.9 & Shanxi & 15 & 1.7 & 0.2 & 1.2 & 1.8 \\
\hline 5 & Neimeng & 15 & 1.8 & 0.1 & 1.5 & 2.0 & Neimeng & 15 & 0.8 & 0.3 & 0.4 & 1.3 \\
\hline 6 & Liaoning & 15 & 3.1 & 0.5 & 2.4 & 4.0 & Liaoning & 15 & 5.5 & 1.3 & 4.2 & 8.2 \\
\hline 7 & Jilin & 15 & 1.8 & 0.3 & 1.4 & 2.3 & Jilin & 15 & 1.4 & 0.4 & 0.9 & 2.0 \\
\hline 8 & Heilongjiang & 15 & 2.5 & 0.2 & 2.1 & 2.9 & Heilongjiang & 15 & 2.5 & 1.2 & 1.3 & 5.6 \\
\hline 9 & Shanghai & 15 & 2.1 & 0.3 & 1.6 & 2.5 & Shanghai & 15 & 9.7 & 3.9 & 5.3 & 15.1 \\
\hline 10 & Jiangsu & 15 & 2.7 & 0.3 & 2.1 & 3.1 & Jiangsu & 15 & 4.9 & 0.5 & 4.0 & 5.6 \\
\hline 11 & Zhejiang & 15 & 2.0 & 0.4 & 1.4 & 2.5 & Zhejiang & 15 & 2.9 & 0.8 & 0.4 & 3.7 \\
\hline 12 & Anhui & 15 & 1.7 & 0.2 & 1.4 & 2.1 & Anhui & 15 & 1.7 & 0.1 & 1.5 & 2.0 \\
\hline 13 & Fujian & 15 & 1.6 & 0.3 & 1.2 & 2.2 & Fujian & 15 & 1.5 & 0.5 & 0.9 & 2.5 \\
\hline 14 & Jiangxi & 15 & 1.5 & 0.1 & 1.3 & 1.6 & Jiangxi & 15 & 1.2 & 0.2 & 0.9 & 1.5 \\
\hline 15 & Shandong & 15 & 3.0 & 0.5 & 2.3 & 3.7 & Shandong & 15 & 4.0 & 0.7 & 2.9 & 5.7 \\
\hline 16 & Henan & 15 & 2.6 & 0.2 & 2.2 & 3.0 & Henan & 15 & 2.8 & 0.2 & 2.4 & 3.2 \\
\hline 17 & Hubei & 15 & 2.4 & 0.2 & 2.1 & 2.7 & Hubei & 15 & 2.8 & 0.2 & 2.5 & 3.1 \\
\hline 18 & Hunan & 15 & 2.2 & 0.2 & 1.9 & 2.5 & Hunan & 15 & 2.4 & 0.3 & 2.0 & 2.9 \\
\hline 19 & Guangdong & 15 & 3.6 & 1.2 & 2.1 & 6.3 & Guangdong & 15 & 4.2 & 1.4 & 2.7 & 8.0 \\
\hline 20 & Guangxi & 15 & 1.7 & 0.2 & 1.4 & 2.0 & Guangxi & 15 & 1.3 & 0.4 & 0.8 & 2.2 \\
\hline 21 & Hainan & 15 & 0.3 & 0.2 & 0.1 & 0.7 & Hainan & 15 & 0.2 & 0.2 & 0.1 & 0.7 \\
\hline 22 & Sichuan & 15 & 3.4 & 0.6 & 2.7 & 4.3 & Sichuan & 15 & 3.5 & 0.6 & 2.7 & 4.7 \\
\hline 23 & Guizhou & 15 & 1.3 & 0.1 & 1.0 & 1.5 & Guizhou & 15 & 0.9 & 0.3 & 0.5 & 1.4 \\
\hline 24 & Yunnan & 15 & 2.2 & 0.6 & 1.4 & 3.8 & Yunnan & 15 & 1.9 & 1.1 & 1.0 & 4.7 \\
\hline 25 & Tibet & 0 & & & & & Tibet & 0 & & & & \\
\hline 26 & Shaanxi & 15 & 1.5 & 0.1 & 1.4 & 1.7 & Shaanxi & 15 & 1.3 & 0.2 & 0.9 & 1.7 \\
\hline 27 & Gansu & 15 & 1.2 & 0.1 & 1.0 & 1.4 & Gansu & 15 & 1.1 & 0.3 & 0.8 & 1.8 \\
\hline 28 & Qinghai & 15 & 0.5 & 0.1 & 0.4 & 0.6 & Qinghai & 15 & 0.2 & 0.1 & 0.1 & 0.3 \\
\hline 29 & Ningxia & 15 & 0.5 & 0.1 & 0.4 & 0.6 & Ningxia & 15 & 0.2 & 0.0 & 0.1 & 0.3 \\
\hline \multirow[t]{2}{*}{30} & Xinjiang & 15 & 1.4 & 0.1 & 1.2 & 1.6 & Xinjiang & 15 & 0.5 & 0.2 & 0.1 & 0.8 \\
\hline & & & 1.9 & 0.3 & 1.5 & 2.4 & & & 2.4 & 0.6 & 1.6 & 3.5 \\
\hline
\end{tabular}

Table A. 2

Fiscal decentralization by province (1994-1999)

\begin{tabular}{|c|c|c|c|c|c|c|c|c|c|c|c|c|}
\hline & \multicolumn{6}{|c|}{ Expenditure decentralization by province (1994-1999) } & \multicolumn{6}{|c|}{ Revenue decentralization by province (1994-1999) } \\
\hline & Province & Obs & Mean & S.D. & Min & Max & Province & Obs & Mean & S.D. & Min & Max \\
\hline 1 & Beijing & 6 & 2.4 & 0.4 & 1.7 & 2.7 & Beijing & 6 & 1.9 & 0.6 & 0.9 & 2.5 \\
\hline 2 & Tianjin & 6 & 1.3 & 0.1 & 1.2 & 1.4 & Tianjin & 6 & 1.0 & 0.0 & 1.0 & 1.1 \\
\hline 3 & Hebei & 6 & 2.8 & 0.1 & 2.7 & 2.9 & Hebei & 6 & 2.0 & 0.1 & 1.8 & 2.1 \\
\hline 4 & Shanxi & 6 & 1.6 & 0.1 & 1.4 & 1.7 & Shanxi & 6 & 1.1 & 0.1 & 1.0 & 1.2 \\
\hline 5 & Neimeng & 6 & 1.6 & 0.0 & 1.5 & 1.6 & Neimeng & 6 & 0.7 & 0.0 & 0.7 & 0.8 \\
\hline 6 & Liaoning & 6 & 3.8 & 0.2 & 3.5 & 4.0 & Liaoning & 6 & 2.8 & 0.2 & 2.4 & 3.0 \\
\hline
\end{tabular}


Table A.2 (Continued)

\begin{tabular}{|c|c|c|c|c|c|c|c|c|c|c|c|c|}
\hline & \multicolumn{6}{|c|}{ Expenditure decentralization by province (1994-1999) } & \multicolumn{6}{|c|}{ Revenue decentralization by province (1994-1999) } \\
\hline & Province & Obs & Mean & S.D. & Min & Max & Province & Obs & Mean & S.D. & Min & $\operatorname{Max}$ \\
\hline 7 & Jilin & 6 & 1.8 & 0.0 & 1.8 & 1.8 & Jilin & 6 & 2.5 & 3.7 & 0.9 & 10.1 \\
\hline 8 & Heilong-jiang & 6 & 2.5 & 0.1 & 2.4 & 2.6 & Heilong-jiang & 6 & 1.6 & 0.1 & 1.5 & 1.7 \\
\hline 9 & Shanghai & 6 & 4.0 & 0.4 & 3.3 & 4.4 & Shanghai & 6 & 3.7 & 0.2 & 3.3 & 3.9 \\
\hline 10 & Jiangsu & 6 & 3.9 & 0.2 & 3.7 & 4.3 & Jiangsu & 6 & 2.9 & 0.2 & 2.6 & 3.0 \\
\hline 11 & Zhejiang & 6 & 2.6 & 0.0 & 2.6 & 2.7 & Zhejiang & 6 & 1.9 & 0.1 & 1.8 & 2.1 \\
\hline 12 & Anhui & 6 & 2.1 & 0.3 & 1.6 & 2.3 & Anhui & 6 & 1.4 & 0.2 & 1.0 & 1.6 \\
\hline 13 & Fujian & 6 & 2.4 & 0.1 & 2.1 & 2.5 & Fujian & 6 & 1.9 & 0.1 & 1.8 & 1.9 \\
\hline 14 & Jiangxi & 6 & 1.6 & 0.0 & 1.6 & 1.7 & Jiangxi & 6 & 1.0 & 0.0 & 0.9 & 1.0 \\
\hline 15 & Shandong & 6 & 4.2 & 0.3 & 3.8 & 4.5 & Shandong & 6 & 3.2 & 0.4 & 2.6 & 3.6 \\
\hline 16 & Henan & 6 & 3.0 & 0.1 & 2.9 & 3.2 & Henan & 6 & 2.0 & 0.1 & 1.8 & 2.2 \\
\hline 17 & Hubei & 6 & 2.5 & 0.1 & 2.4 & 2.6 & Hubei & 6 & 1.6 & 0.1 & 1.5 & 1.7 \\
\hline 18 & Hunan & 6 & 2.6 & 0.1 & 2.4 & 2.7 & Hunan & 6 & 1.6 & 0.1 & 1.5 & 1.8 \\
\hline 19 & Guangdong & 6 & 7.5 & 0.2 & 7.2 & 7.7 & Guangdong & 6 & 6.3 & 0.3 & 5.7 & 6.7 \\
\hline 20 & Guangxi & 6 & 1.9 & 0.2 & 1.7 & 2.1 & Guangxi & 6 & 1.2 & 0.0 & 1.1 & 1.3 \\
\hline 21 & Hainan & 6 & 0.6 & 0.1 & 0.4 & 0.7 & Hainan & 6 & 0.4 & 0.1 & 0.3 & 0.5 \\
\hline 22 & Sichuan & 6 & 4.1 & 0.1 & 3.9 & 4.1 & Sichuan & 6 & 2.7 & 0.1 & 2.5 & 2.8 \\
\hline 23 & Guizhou & 6 & 1.3 & 0.0 & 1.2 & 1.3 & Guizhou & 6 & 0.6 & 0.0 & 0.6 & 0.7 \\
\hline 24 & Yunnan & 6 & 3.3 & 0.3 & 2.9 & 3.5 & Yunnan & 6 & 1.6 & 0.1 & 1.5 & 1.8 \\
\hline 25 & Tibet & 5 & 0.4 & 0.0 & 0.4 & 0.5 & Tibet & 5 & 0.1 & 0.1 & 0.0 & 0.3 \\
\hline 26 & Shaanxi & 6 & 1.5 & 0.0 & 1.5 & 1.6 & Shaanxi & 6 & 0.9 & 0.1 & 0.8 & 0.9 \\
\hline 27 & Gansu & 6 & 1.2 & 0.0 & 1.1 & 1.2 & Gansu & 6 & 0.5 & 0.0 & 0.5 & 0.6 \\
\hline 28 & Qinghai & 6 & 0.4 & 0.0 & 0.4 & 0.4 & Qinghai & 6 & 0.1 & 0.0 & 0.1 & 0.1 \\
\hline 29 & Ningxia & 6 & 0.4 & 0.0 & 0.3 & 0.4 & Ningxia & 6 & 0.2 & 0.0 & 0.1 & 0.2 \\
\hline \multirow[t]{2}{*}{30} & Xinjiang & 6 & 1.3 & 0.1 & 1.2 & 1.4 & Xinjiang & 6 & 0.6 & 0.0 & 0.5 & 0.7 \\
\hline & & & 2.3 & 0.1 & 2.2 & 2.5 & & & 1.7 & 0.2 & 1.4 & 2.1 \\
\hline
\end{tabular}

\section{References}

Ahmad, E., Gao, Q., \& Tanzi, V. (Eds.). (1995). Reforming China's public finances. Washington, D.C. International Monetary Fund.

Akai, N., \& Sakata, M. (2002). Fiscal decentralization contributes to economic growth: Evidence from state-level crosssection data for the United States. Journal of Urban Economics, 52, 93-108.

Bahl, R. (1999). Fiscal policy in China: Taxation and intergovernmental fiscal relations. The 1990 Institute.

Bahl, R., Wallich, C. (1992). Intergovernmental fiscal relations in China. Research Working Paper 863. Washington, D.C.: Development Research Group, World Bank.

Barro, R. (1990). Government spending in a simple model of endogenous growth. Journal of Political Economy, 98, 103125.

Bird, R. (1992). Tax policy and economic development. Baltimore: Johns Hopkins University Press.

Brueckner, J. K. (2000). Fiscal decentralization in developing countries: The effects of local corruption and tax evasion. Annals of Economics and Finance, 1(1), 1-18.

China Finance Statistical Yearbook. Various issues.

China Statistical Yearbook. Various issues.

Davoodi, H., \& Zou, H. F. (1998). Fiscal decentralization and economic growth: A cross-country study. Journal of Urban Economics, 43, 244-257.

Ebel, R., Yilmaz, S. (2001). On the measurement and impact of fiscal decentralization. Policy Research Working Paper 2809. Washington D.C.: The World Bank.

Feder, G. (1983). On exports and economic growth. Journal of Development Economics, 12, 59-73.

Hseh, T., Li, Q., \& Liu, S. C. (Eds.). (1993). China's provincial statistics 1949-89. Boulder: Westview Press.

Jin, H. H., Qian, Y. Y., \& Weingast, B. R. (1999). Regional decentralization and fiscal incentives: federalism, Chinese style. Mimeo, Stanford University. 
Jin, J., \& Zou, H. F. (1999). Fiscal decentralization and economic growth. Mimeo, Washington, D.C. World Bank.

Jin, J., Zou, H. F. (2003). Soft budget constraints on local government in China. In Rodden, Eskeland, \& Litvack (Eds.), Fiscal decentralization and the challenge of hard budget constraints. MIT Press.

Mello, L. R. D. (2000). Fiscal decentralization and intergovernmental fiscal relations: A cross-country analysis. World Development, 28(2), 365-380.

Musgrave, R. A. (1983). Whose should tax, where, and what? In C., McLure, Jr., (Ed.). Tax assignment in federal countries. Canberra: Australian National University Press.

Oates, W. (1972). Fiscal federalism. New York: Harcourt Brace Jovanovich.

Oates, W. (1993). Fiscal decentralization and economic development. National Tax Journal, XLVI, $237-243$.

Oi, J. C. (1992). Fiscal reform and the economic foundations of local state corporatism in China. World Politics, 45(1), 99126.

Prud'homme, R. (1995). On the dangers of decentralization. The World Bank Research Observer, 10(2), $201-220$.

Qian, Y. Y. (1999). The institutional foundations of China's market transition. Annual World Bank Conference on Development Economics.

Qian, Y. Y., \& Weingast, B. R. (1997). Federalism as a commitment to preserving market incentives. The Journal of Economic Perspectives, 11(4), 83-92.

Shah, A. (1994). The reform of intergovernmental fiscal relations in developing and emerging market economies. Policy and Research Series, 23. The World Bank, Washington, D.C.

Steinfeld, E. (1999). Forging reform in China: The fate of state-owned industry. Cambridge: Cambridge University Press.

Tanzi, V. (1996). Fiscal federalism and decentralization: A review of some efficiency and macroeconomic aspects. Annual World Bank Conference on Development Economics 1995.

Tiebout, C. (1956). A pure theory of local expenditures. Journal of Political Economy, 64, 416-424.

Wang, S. G. (1997). China's fiscal reform in 1994: An initial assessment. Asian Survey, 37, 801-817.

Wong, C. P. W. (1991). Central-local relations in an era of fiscal decline: The paradox of fiscal decentralization in postMao China. The China Quarterly, 128, 691-715.

World Bank. (1989). China: Revenue mobilization and tax policy: issues and options. Report No. 7605-CHA. Washington, D.C.

World Bank. (1993). China: Budgetary policy and intergovernmental fiscal relations. Report No. 11094-CHA. Washington, D.C.

Xie, D. Y., Zou, H. F., \& Davoodi, H. (1999). Fiscal decentralization and economic growth in the Unites States. Journal of Urban Economics, 45, 228-239.

Yang, D. L. (1997). Beyond Beijing: Liberalization and the regions in China. London: Routledge.

Young, A. (2000). The Razor's Edge: Distortions and incremental reform in the People's Republic of China. NBER Working Paper 7828.

Yusuf, S. (1994). China's macroeconomic performance and management furing transition. Journal of Economic Perspective, 8(2), 71-92.

Zhang, T., \& Zou, H. F. (1998). Fiscal decentralization, public spending and economic growth in China. Journal of Public Economics, 67, 221-240. 